Rowan University

Rowan Digital Works

4-1-2017

\title{
An Evaluation Framework for Selecting Collaboration Systems for Student Teamwork
}

Yide Shen

Rowan University

Lei Li

Kennesaw State University

Guangzhi Zheng

Kennesaw State University

Rong Guo

University of West Georgia

Follow this and additional works at: https://rdw.rowan.edu/business_facpub

Part of the Computer Sciences Commons, and the Higher Education Commons

\section{Recommended Citation}

Shen, Y., Li, L., Zheng, G., \& Guo, R. (2017). An Evaluation Framework for Selecting Collaboration Systems for Student Teamwork. International Journal of Information and Communication Technology Education, 13(2), 65-81.

This Article is brought to you for free and open access by the Rohrer College of Business at Rowan Digital Works. It has been accepted for inclusion in Rohrer College of Business Faculty Scholarship by an authorized administrator of Rowan Digital Works. 


\title{
An Evaluation Framework for Selecting Collaboration Systems for Student Teamwork
}

\author{
Yide Shen, Rohrer College of Business, Rowan University, Glassboro, NJ, USA \\ Lei Li, College of Computing and Software Engineering, Kennesaw State University, Kennesaw, GA, USA \\ Guangzhi Zheng, College of Computing and Software Engineering, Kennesaw State University, Kennesaw, GA, USA \\ Rong Guo, Richard College of Business, University of West Georgia, Carrollton, GA, USA
}

\begin{abstract}
Collaboration technologies play an increasingly important role in student teamwork in universities. With the proliferation of collaboration systems on the market and the wide range of features they offer, choosing an appropriate system can be an overwhelming task for college students. In this paper, the authors present an empirical study that aimed to help college instructors and students assess and select appropriate collaboration systems for their teamwork needs. They first identified and ranked the important features of collaboration systems for students through a web-based survey. Based on the survey results, the authors built an evaluation framework, in the form of weighted scoring tables, to help students systematically choose technologies that met their collaborative needs. They further demonstrated how to use those scoring tables for an undergraduate capstone class that had a termlong team project. The implications and future directions of the authors' study are also discussed.
\end{abstract}

\section{KEYWORDS}

Collaboration Systems, Empirical Examination, Evaluation Framework, Group Projects, Teamwork

\section{INTRODUCTION}

Teamwork skills are vital for today's college graduates (Aasheim, Shropshire, Lixin, \& Kadlec, 2012; Ahmed, Capretz, \& Campbell, 2012; Robles, 2012). According to a recent study that examined core competencies of college graduates, teamwork or collaboration is consistently cited as a key workplace skill in multiple studies that surveyed recruiters, HR professionals, hiring managers and executives (Eisner, 2010). Meanwhile, with a changing workplace environment characterized by globalization, cost-cutting, cross-functional projects and mobility, organizations increasingly rely on collaboration technologies to support teamwork (Alnuaimi, Robert Jr., \& Maruping, 2010; Brown, Dennis, \& Venkatesh, 2010). This increases the demand for college graduates who possess the skills to effectively use collaboration technologies to achieve team goals (Staggers, Garcia, \& Nagelhout, 2008). 
In an effort to prepare students to have such skills, educators and researchers have provided advice to teams on how to build virtual collaboration skills by using a specific technology platform (Long \& Meglich, 2013) as well as how to choose appropriate technology for virtual team meetings (Bull Schaefer \& Erskine, 2012). However, collaboration technologies provide many more features beyond supporting virtual team meetings, such as sharing documents, tracking activities, planning and scheduling tasks, and coordinating member efforts (Dumova \& Fiordo, 2009). Given the proliferation of collaboration tools on the market and the wide range of features they offer, choosing and using appropriate tools can be an overwhelming task for college students. Thus, students still face challenges choosing appropriate collaboration tools to meet their specific team needs.

To address this challenge, we conducted an empirical study to develop an evaluation framework that can be used by college students to assess and select appropriate collaboration technologies that fit their needs. In the rest of the paper, we review the prior studies on the use of collaboration technologies in college student teams, present a detailed research design, describe an evaluation framework we created based on our research results, and discuss the implications of the study.

\section{LITERATURE REVIEW}

Collaboration technology supports multiple people working together regardless of their physical locations or whether they work at the same time or at different times (Dennis, George, Jessup, Nunamaker Jr., \& Vogel, 1988; DeSanctis \& Gallupe, 1987). Examples of early collaboration technologies include e-mail (Markus, 1994), group decision support systems (DeSanctis \& Gallupe, 1987), and web-based conferencing systems (Warkentin, Sayeed, \& Hightower, 1997). In recent years, features provided by collaboration technology have expanded greatly, including: sharing documents; presenting, sharing and annotating a screen; polling participant status; recording meetings; tracking activities; planning and scheduling; and coordinating member efforts (Dumova \& Fiordo, 2009; Xu, 2007).

With the growing trend of using collaboration systems to support teamwork (Alnuaimi et al., 2010; Brown et al., 2010), organizations are seeking employees who know how to effectively use these technologies (Staggers et al., 2008). To respond to such needs, a number of studies have been conducted in areas such as teaching the use of collaboration technologies to students (Long \& Meglich, 2013; Staggers et al., 2008), investigating critical technology-related issues that influence student virtual project team performance (Weimann, Pollock, Scott, \& Brown, 2013), and choosing appropriate technology for virtual team meetings in class projects (Bull Schaefer \& Erskine, 2012). Despite their significant contributions to prepare students for real-life teamwork using collaboration technologies, a few areas are still under-addressed by this body of research.

First, with one exception (Weimann et al., 2013), most research has focused on virtual teams without considering traditional face-to-face teams or hybrid teams where members have in person meetings. However, as recognized by Weimann and colleagues (2013), although student teams are not usually spread across geographic locations, they often have limited face-to-face meetings due to team members' different class and work schedules, especially for graduate students and students who take online classes. When the line between traditional and virtual teams is blurred (Gaudes, Hamilton-Bogart, Marsh, \& Robinson, 2007), it is important to consider all types of team technology needs for effective teamwork, which is still lacking in the literature.

Second, when it comes to choosing appropriate tools, student teams may consider a different set of factors (e.g., low or no cost) and have unique sets of needs from "real world" teams. For example, students are not necessarily constrained by organizational standards or policies like those posed in a corporate environment (Majchrzak, Rice, Malhotra, King, \& Ba, 2000). They may also utilize systems and tools that are primarily used for personal purposes, including social media, which are more widely used and convenient. We are not aware of any research that has investigated the features of collaboration technology that are critical to students in an educational environment. 
Third, although researchers have recognized the importance of selecting the right collaboration technology (Bull Schaefer \& Erskine, 2012; Weimann et al., 2013), we have not found research that has investigated how to guide students to choose appropriate systems for their teamwork needs (except for virtual meetings, which were investigated by Bull, Schaefer and Erskine 2012). This is an important topic since research has shown that the improper selection of communication and collaboration tools introduces discontinuities in project work and impacts team performance (Weimann et al., 2013). At the same time, with a wide range of collaboration tools and an overwhelming number of features to consider, students may have difficulties agreeing on a system for their teamwork needs.

To fill this research gap, we conducted an empirical study to develop an evaluation framework that is tailored to college students' need of assessing and selecting appropriate collaboration technologies in an educational environment. The research design is discussed in the next section.

\section{RESEARCH DESIGN}

Grounded in Task-Technology Fit theory (Goodhue \& Thompson, 1995), we believe that the best collaboration systems for student teamwork are those that best meet their collaboration needs. We created a web-based survey to identify the important features in collaboration technology that are used for student teamwork. Based on the survey results, we developed an evaluation framework in the form of a scoring table to help students systematically select the right collaboration technology tools for their needs.

The web-based questionnaire (see Appendix A) was administered to both undergraduate and graduate students. Based on a survey used by Xu (2007), the questionnaire was adapted to collect information about students' experiences with collaboration technologies and their opinions on the importance of the technologies' features. We identified four major categories of features: document (file) and content sharing, team communication, project/task management, and additional access features such as mobile device support and integration of social networking sites. We also included utilities of collaboration technologies (such as ease of use and cost) as an additional category. Each main category has a set of more specific features/items. Our goal was to develop a comprehensive set of collaboration technology features from the survey and ask participants to rate their importance.

The questionnaire was distributed to 226 students majoring in information technology (IT) at a regional public university in the southeastern United States over two consecutive semesters. The courses from which we recruited students included online and hybrid (50 percent online) courses at both the graduate and undergraduate levels. The survey was anonymous and participation was voluntary. We received 195 responses for a response rate of 86 percent. Five responses were deleted because they were completed in less than one minute. Thus, we had 190 valid responses.

\section{RESEARCH FINDINGS}

\section{Survey Results}

\section{Demographic Information}

Among all respondents, the majority (66 percent) was male and 42 percent were younger than 30 years old. The majority of respondents ( 82 percent) were graduate students. Seventy-two percent of the participants had more than three years of work experience. The demographic information is consistent with the general student population of the participating IT department. With regard to students' past experience with team projects, 92 percent of the respondents had worked in at least one team project and 33 percent had worked in more than six team projects.

\section{Use of Collaboration Technology Products and Participants'Attitudes}


Only 52 percent of the participants had used some kind of collaboration technology in their class team projects. Thirty-seven different collaboration technologies were mentioned by the respondents ranging from commercial tools such as Microsoft SharePoint and Citrix GotoMeeting, to free-to-use Google products, and to many other commercial or free collaboration technologies.

The top four reasons for not using collaboration technology were:

1. Not familiar with collaboration technology products (51 percent)

2. Cost of the collaboration technology product ( 22 percent)

3. The collaboration technology product lacked features I wanted (17 percent)

4. The collaboration technology product was difficult to use (16 percent)

This finding is somewhat surprising since our subjects are IT students and they should be more comfortable using technology. This could be explained by the fact that a majority of the participants are graduate students who did not gain a computing background in their undergraduate studies.

The majority of the participants thought that collaboration technology would be helpful in their team projects. Fifty-seven percent of the respondents indicated that collaboration technology is useful for teamwork in on-campus classes while 77 percent held the same belief for online classes.

In summary, the survey respondents confirmed that collaboration technology would be helpful in their teamwork and they used a wide range of collaboration tools. It's important to have an evaluation framework that can guide the users in effectively selecting the right collaboration technology.

\section{Important Features of Collaboration Technology}

In the survey, we listed four categories of collaboration technology features plus their utilities (i.e., cost, ease of use and installation). We asked the participants to indicate the importance of each feature category using a five-point scale ( 1 - very unimportant, 2 - somewhat unimportant, 3 - neutral, 4 somewhat important and 5 - very important). The input from participants is summarized in Table 1.

The top rated feature of a collaboration technology is document (file) and content sharing, followed by team communication and cost of the collaboration technology. We used team communication as a general term that includes both synchronous communication, such as video chat, and asynchronous communication, such as email. Project management features also received a high rating. The mean of the rated importance score for project management is lower than that of the team communication, even though their percentage of rated importance scores were similar. This was because more participants

Table 1. Top rated collaboration technology features

\begin{tabular}{|c|c|c|c|c|}
\hline \multicolumn{2}{|c|}{$\begin{array}{c}\text { Feature/Utility of collaboration technology } \\
\text { product }\end{array}$} & $\begin{array}{l}\text { Mean of rated } \\
\text { "Important" }\end{array}$ & $\begin{array}{l}\text { Percent rated } \\
\text { "Importance" }\end{array}$ & $\begin{array}{l}\text { Percent rated } \\
\text { "Very Important" }\end{array}$ \\
\hline \multicolumn{2}{|c|}{ Document (file) and content sharing } & 4.39 & $84.86 \%$ & $67.57 \%$ \\
\hline \multicolumn{2}{|c|}{ Team communication } & 4.34 & $81.62 \%$ & $65.95 \%$ \\
\hline \multicolumn{2}{|c|}{ Project management (task management) } & 4.15 & $80.98 \%$ & $49.46 \%$ \\
\hline \multicolumn{2}{|c|}{$\begin{array}{l}\text { Additional features for mobile support, } \\
\text { interaction with existing social networking sites, } \\
\text { and others }\end{array}$} & 3.61 & $54.89 \%$ & $31.90 \%$ \\
\hline \multirow{3}{*}{ Utility } & Cost & 4.24 & $78.92 \%$ & $59.46 \%$ \\
\hline & Ease of use & 4.48 & $87.79 \%$ & $71.51 \%$ \\
\hline & Ease of installation & 4.46 & $87.72 \%$ & $68.42 \%$ \\
\hline
\end{tabular}

Note: "Percent rated important" is calculated by dividing the number of participants who rated the feature as very important and somewhat important by the total number of participants. 
rated team communication as "very important" than they did project management. Additional features such as mobile support and social media connections were not very important to the respondents. The utilities of collaboration technology included cost, ease of use, and ease of installation. The participants gave high ratings on the utilities. The survey results for these major categories form a strong foundation for building an evaluation framework to assess different collaboration technologies in the market.

Our questionnaire also included a set of more detailed features/items under each main category. Similar to the main feature categories, we asked the participants to indicate the importance of each specific feature/item using the same five-point scale used for the feature categories $(1-$ very unimportant, 2 - somewhat unimportant, 3 - neutral, 4 - somewhat important and 5 - very important). Results for the detailed features/items for each main feature category are summarized in Tables 2 to 5. The survey results for these features and items provided additional information for tailoring the evaluation framework to different settings. The evaluation framework and its use in different settings are discussed in the next section.

Table 2. The importance of features in file and content sharing

\begin{tabular}{|l|l|l|}
\hline \multicolumn{1}{|c|}{ File and content sharing feature } & \multicolumn{1}{|c|}{$\begin{array}{c}\text { Mean of rated } \\
\text { "Important" }\end{array}$} & \multicolumn{1}{c|}{$\begin{array}{c}\text { Percent rated } \\
\text { "Important" }\end{array}$} \\
\hline Central storage facility (document repository) & 4.36 & $83.14 \%$ \\
\hline Permissions to manage access & 4.26 & $79.29 \%$ \\
\hline Options to organize files / documents in folders by projects & 4.23 & $80.59 \%$ \\
\hline Searching across documents & 4.21 & $78.95 \%$ \\
\hline $\begin{array}{l}\text { Integration with cloud storage such as Dropbox, Box, Google Drive, One } \\
\text { Drive }\end{array}$ & 4.18 & $76.02 \%$ \\
\hline Document check in and check out & 4.17 & $78.36 \%$ \\
\hline Version control & 4.11 & $75.88 \%$ \\
\hline Document conversion (to other formats, compatibility) & 4.06 & $75.43 \%$ \\
\hline Document subscription for alerts on changes & 4.05 & $73.56 \%$ \\
\hline Summary document previews & 3.94 & $67.84 \%$ \\
\hline
\end{tabular}

Table 3. The importance of features in project management

\begin{tabular}{|l|l|l|}
\hline \multicolumn{1}{|c|}{ Project management feature } & \multicolumn{1}{|c|}{$\begin{array}{c}\text { Mean of rated } \\
\text { 'Important" }\end{array}$} & \multicolumn{1}{|c|}{$\begin{array}{c}\text { Percent rated } \\
\text { "Important" }\end{array}$} \\
\hline $\begin{array}{l}\text { Capabilities to assign tasks to team members and track their } \\
\text { progress }\end{array}$ & 4.31 & $83.82 \%$ \\
\hline Options to create and manage project tasks & 4.30 & $83.43 \%$ \\
\hline $\begin{array}{l}\text { Ability to monitor team's status and progress to prevent } \\
\text { bottlenecks }\end{array}$ & 4.26 & $83.24 \%$ \\
\hline Options to set milestones & 4.26 & $83.43 \%$ \\
\hline Options to balance team workload & 4.17 & $80.23 \%$ \\
\hline Options for project reports & 4.05 & $72.94 \%$ \\
\hline Gantt charting & 3.91 & $70.70 \%$ \\
\hline
\end{tabular}


Table 4. The Importance of features in team communication

\begin{tabular}{|l|l|l|}
\hline \multicolumn{1}{|c|}{ Team communication feature } & $\begin{array}{c}\text { Mean of rated } \\
\text { "Important" }\end{array}$ & \multicolumn{1}{|c|}{$\begin{array}{c}\text { Percent rated } \\
\text { "Important" }\end{array}$} \\
\hline Options for document presentation during meetings & 4.22 & $83.72 \%$ \\
\hline $\begin{array}{l}\text { Instant messaging (chat) with options to share desktop, give control and send } \\
\text { files }\end{array}$ & 4.20 & $80.23 \%$ \\
\hline Options to schedule meetings dynamically and flexibly & 4.15 & $80.68 \%$ \\
\hline Ability to view and edit documents at the same time as other group members & 4.15 & $76.74 \%$ \\
\hline Ability to perform presentations online & 4.14 & $79.89 \%$ \\
\hline Audio (VoIP) / video conferencing options & 4.08 & $75.14 \%$ \\
\hline Message boards for topic discussion and announcements & 4.07 & $77.01 \%$ \\
\hline Capabilities to record meetings and share meeting notes & 4.01 & $72.83 \%$ \\
\hline Options for voice communication & 4.00 & $72.32 \%$ \\
\hline Options for sharing group calendars & 3.99 & $75.00 \%$ \\
\hline $\begin{array}{l}\text { Email tools and compatibility with other email management tools such as MS } \\
\text { Outlook }\end{array}$ & 3.97 & $71.84 \%$ \\
\hline Workflow feature to allow documents to be routed through process & 3.95 & $70.93 \%$ \\
\hline Ability to call a phone number such as international and local phone numbers & 3.68 & $57.56 \%$ \\
\hline Options to create polls and surveys from discussion topics (Polling) & 3.59 & $57.89 \%$ \\
\hline
\end{tabular}

Table 5. The Importance of additional features in collaboration technology

\begin{tabular}{|l|l|l|}
\hline \multicolumn{1}{|c|}{ Additional feature } & $\begin{array}{c}\text { Mean of rated } \\
\text { "Important" }\end{array}$ & \multicolumn{1}{|c|}{$\begin{array}{c}\text { Percent rated } \\
\text { "Important" }\end{array}$} \\
\hline Online updates and technical support & 4.27 & $80.72 \%$ \\
\hline $\begin{array}{l}\text { Mobile accessibility to join meetings, send instant messages or give project } \\
\text { inputs through Apple or Android devices }\end{array}$ & 4.25 & $78.86 \%$ \\
\hline Options for security like encryption and login & 4.09 & $73.99 \%$ \\
\hline Diversity support (time zones, meeting schedules, support different languages) & 3.95 & $68.39 \%$ \\
\hline Capability for wiki (options to view and edit websites with project comments) & 3.72 & $61.40 \%$ \\
\hline Blog options to facilitate group discussions through posts and comments & 3.64 & $55.56 \%$ \\
\hline $\begin{array}{l}\text { Options to interact with existing social networking sites like Facebook or } \\
\text { MySpace }\end{array}$ & 3.34 & $46.51 \%$ \\
\hline
\end{tabular}

\section{Development the Evaluation Framework}

An evaluation framework is critical for helping targeted users objectively and effectively select the appropriate collaboration technology product(s). Based on the rated importance of collaboration technology features from the survey, a weighted scoring table was developed as the evaluation framework. Table 6 is the scoring table for the five main categories of collaboration technology features. In this table, the Rating column is where users of the scoring table give a rating to the category based on their own assessment, using a 10-point scale. The values in the Importance Factor column were derived from the rated importance in our survey results. We used a 5-point scale in our 
survey, in which 1 represents least important, 3 represents neutral, and 5 represents most important. In Table 6, the importance factor for each category was calculated using a rated importance score from our survey results divided by the highest importance point. For example, if the rated importance of team communication is 4.34, its importance factor is 0.87 (4.34 divided by 5 ). The last column of the score table, Weighted Rating, is the product of Rating by Importance Factor.

After users complete their assessment of a collaboration technology product and give a rating for each feature, they can determine which collaboration technology best fits their needs by looking at the total weighted rating of each product. The higher the total weighted rating, the better the technology fits their needs.

\section{Using the Evaluation Framework}

In this section, we describe how our evaluation framework presented above could be used. When users' teamwork setting is similar to the setting presented in this paper, users can assess the collaboration technology using the evaluation framework (as shown in Table 6) in its current format. Users can start by identifying a broad range of available collaboration technology products in the market and perform an assessment using the scoring table with the main feature categories (i.e., Table 6). If no product stands out from this round of evaluation, users can perform a more thorough analysis using customized scoring tables containing specific features under each main category (i.e., those presented in Tables 3 to 5). Although we did not present scoring tables containing specific features in the current paper, our survey results provided rated importance scores for these features, which can be used to develop customized weighted scoring tables tailored to a user's needs. In either case, the assessment process should also include installation and actual use of the collaboration technology. At the end, the evaluators should discuss their findings, reconcile any differences, and select one or more collaboration technology products. The recommendation may include a standalone collaboration technology product or a combination of products.

If users' teamwork setting is dramatically different from our sample setting, they can adopt the approach we discussed above (survey users, identify important features and importance factors) and develop their own framework. In summary, our survey results, as well as the approach we presented above to develop the evaluation framework (i.e., scoring table), provide flexibility for users when their team settings call for a different set of specific features to be evaluated. In the next section, we present an example to demonstrate how the framework was used to select appropriate collaboration technology products for student teams in an undergraduate IT capstone class in a regional public state university.

Table 6. Evaluation framework - A scoring table

\begin{tabular}{|l|l|l|l|}
\hline Feature/Utility of collaboration technology products & Rating (1-10) & Importance Factor & Weighted Rating \\
\hline Document (file) and content sharing & & 0.88 & \\
\hline Team communication & & 0.87 & \\
\hline Project management (task management) & & 0.83 & \\
\hline Additional features & & 0.72 & \\
\hline Utilities & & 0.88 & \\
\hline Overall fit of the collaboration technology tool & & \\
\hline
\end{tabular}

Notes: 1. Rating: on a scale of 1-10, where 1 is "does not fit my team's needs at all" and 10 is "completely fits my team's need", how would you rate this feature of the collaboration tool that you are evaluating?

2. Weighted Rating $=$ Rating $x$ Importance Factor

3. Overall fit of the collaboration technology tool = Sum of Weighted Rating (higher score indicates better fit) 


\section{An Example of Using the Evaluation Framework}

In an undergraduate IT capstone class, students need to collaborate in a term long team project. Four students in this class were chosen as evaluators. They were given the complete evaluation framework including the main feature categories and all specific features under each main category.

The evaluators first used the scoring table containing the main feature categories to examine a wide range of collaboration technologies on the market. Table 7 presents a scoring table the evaluators used to evaluate Skype. By comparing the sum of the weighted rating of each product, the evaluation team was not able to pick a clear winner, but was able to narrow down to four collaboration technology products: Skype, Wrike, Feng, Google Drive/Hangout.

In the second phase of the evaluation, the evaluators examined the final four products in greater detail. They used the scoring tables containing specific features under each main category in the process. Each evaluator was assigned two tools. The evaluators installed the tools to be evaluated and used them for a short period of time in order to assign more accurate scores to each feature. Each tool was assessed by two evaluators. The scoring tables from the evaluators were compared and differences were reconciled by thorough discussion. Finally, Google Drive/Hangout was chosen by the evaluators, based on the sum of weighted ratings for each tool. The recommendation is also consistent with our survey results that showed that Google Drive/Hangout was the most popular collaboration technology reported by survey participants.

\section{DISCUSSION}

It is not surprising that the feature of document and content sharing was ranked the most important feature for team projects, with "Central Storage Facility" as the most important feature of all. This reflects a greater need for document sharing as most of the projects produce large quantities of files, including write-ups with different versions, collected resources and references, and other instructional files or guides. Central storage makes sure the single, shared version of the work is available and maintained, and that the completeness of the resources and works is captured. From our survey, we find that the needs for concurrent control such as version control, check-in/out, and subscription to alerts are not the features students value as most important. Rather, students are more focused on basic document management support.

The second main feature is team communication and collaboration. In today's work environment, working with people remotely in different locations has become common. This is also true for college students, especially senior and graduate students. Most of them have part time or full time work, and very different schedules. It becomes difficult to hold synchronous group meetings in one location. Support for timely communication and virtual meetings is greatly needed. Besides simple communication support, students listed many features for advanced collaboration, such as document presentation, collaborative editing, video conferencing, and dynamic meeting scheduling. They value these features more than basic email and phone call support.

Table 7. Example scoring table for Skype

\begin{tabular}{|l|l|l|l|}
\hline Feature/Utility of collaboration technology products & Rating (1-10) & Importance Factor & Weighted Rating \\
\hline Document (file) and content sharing & 3 & 0.88 & 2.64 \\
\hline Team communication & 10 & 0.87 & 8.7 \\
\hline Project management (task management) & 1 & 0.83 & 0.83 \\
\hline Additional features & 8 & 0.72 & 5.76 \\
\hline Utilities & 10 & 0.88 & 8.8 \\
\hline Overall fit of the collaboration technology tool & & 26.73 \\
\hline
\end{tabular}


The project and task management category did not rank as highly as the first two categories. This may due to course requirements. In most class projects, students are evaluated on project outcomes, with no emphasis on project and task management practices. In our sample, about 20 percent of the responses came from students who were in a capstone project, where project management practices (such as planning, scheduling, and progress monitoring) were specifically required and evaluated. For the rest of our sample, however, no such requirements were specified for student projects.

It is also worth noting that about half of the students surveyed stated that they did not usually use any technology product to support team collaboration. The top reason is unfamiliarity with these technologies. This implies the opportunity and potential to enhance teamwork by assisting students in evaluating and choosing collaboration systems. It is also an indicator to educators that students may need specific training in using collaboration systems and tools.

\section{LIMITATIONS AND FUTURE RESEARCH}

This study has a number of limitations that also point to future research opportunities. First, our respondents were mainly drawn from three graduate classes in an IT program, where group projects are a small part of the class and do not focus on technical practices and solutions. Thus, their views might be more weighted on features of document sharing. We intended to garner more responses from undergraduate students in capstone courses, in which they are required to do a semester-long group project where collaboration is essential and intense.

Second, at this time, we are targeting collaboration in formal class projects within a course. It would be valuable to expand the study to more contexts and generalize our findings for the whole educational environment, including extracurricular collaborations across courses or even departments; collaborations between faculty and students; and collaborations among faculty for the purpose of teaching, research and service.

Third, some common features of collaboration, such as knowledge management, socialization, and collaborative task support, were not included in the initial survey, as they are not used widely in student projects. As we expand our application domains, these features may become important.

Last, we plan to evaluate its effectiveness of the collaboration technology identified in this paper by using the technology for student teamwork in a controlled university setting with a control group and a treatment group.

\section{CONCLUSION}

Bounded in the college environment, this study presents an evaluation framework that can be used by college instructors and students to assess and select appropriate collaboration systems that fit their teamwork needs. This study contributes to both research and pedagogical practices in the IS/IT field. For collaboration systems research, this study empirically identified and ranked important features of collaboration systems in an education context. The evaluation framework with ranked system features, as well as the research methodology, could be adapted to assess collaboration technology in other domains. For IS/IT pedagogical practices, instructors and students can use the evaluation framework to choose and recommend collaboration technology products to student teams. The research methodology can also be used as an exemplar for product selection for different types of projects. 


\section{REFERENCES}

Aasheim, C., Shropshire, J., Lixin, L., \& Kadlec, C. (2012). Knowledge and Skill Requirements for Entry-Level IT Workers: A Longitudinal Study. Journal of Information Systems Education, 23(2), 193-204.

Ahmed, F., Capretz, L. F., \& Campbell, P. (2012). Evaluating the Demand for Soft Skills in Software Development. IT Professional, 14(1), 44-49. doi:10.1109/MITP.2012.7 PMID:23397361

Alnuaimi, O. A., Robert, L. P. Jr, \& Maruping, L. M. (2010). Team Size, Dispersion, and Social Loafing in Technology-Supported Teams: A Perspective on the Theory of Moral Disengagement. Journal of Management Information Systems, 27(1), 203-230. doi:10.2753/MIS0742-1222270109

Brown, S. A., Dennis, A. R., \& Venkatesh, V. (2010). Predicting Collaboration Technology Use: Integrating Technology Adoption and Collaboration Research. Journal of Management Information Systems, 27(2), 9-53. doi:10.2753/MIS0742-1222270201

Bull Schaefer, R. A., \& Erskine, L. (2012). Virtual Team Meetings: Reflections on a Class Exercise Exploring Technology Choice. Journal of Management Education, 36(6), 777-801. doi:10.1177/1052562912436912

Dennis, A. R., George, J. F., Jessup, L. M., Nunamaker, J. F. Jr, \& Vogel, D. R. (1988). Information Technology to Support Electronic Meetings. Management Information Systems Quarterly, 12(4), 591-624. doi:10.2307/249135

DeSanctis, G., \& Gallupe, R. B. (1987). A Foundation for the Study of Group Decision Support Systems. Management Science, 33(5), 589-609. doi:10.1287/mnsc.33.5.589

Dumova, T., \& Fiordo, R. (2009). Handbook of research on social interaction technologies and collaboration software; concepts and trends (Vol. 24). Portland: Ringgold Inc.

Eisner, S. (2010). Grave New World? Workplace Skills for Today's College Graduates. American Journal of Business Education, 3(9), 27-50.

Gaudes, A., Hamilton-Bogart, B., Marsh, S., \& Robinson, H. (2007). A framework for constructing effective virtual teams. Journal of E-Working, 1, 83-97.

Goodhue, D. L., \& Thompson, R. L. (1995). Task-Technology Fit and Individual Performance. Management Information Systems Quarterly, 19(2), 213-236. doi:10.2307/249689

Long, L. K., \& Meglich, P. A. (2013). Preparing students to collaborate in the virtual work world. Higher Education, Skills and Work - Based Learning, 3(1), 6-16. doi:10.1108/20423891311294948

Majchrzak, A., Rice, R. E., Malhotra, A., King, N., \& Ba, S. (2000). Technology adaptation: The case of a computer-supported inter-organizational virtual team. Management Information Systems Quarterly, 24(4), 569-600. doi:10.2307/3250948

Markus, M. L. (1994). Electronic Mail as the Medium of Managerial Choice. Organization Science, 5(4), 502-527. doi:10.1287/orsc.5.4.502

Robles, M. M. (2012). Executive Perceptions of the Top 10 Soft Skills Needed in Todays Workplace. Business Communication Quarterly, 75(4), 453-465. doi:10.1177/1080569912460400

Staggers, J., Garcia, S., \& Nagelhout, E. (2008). Teamwork through team building: Face-to-face to online. Business Communication Quarterly, 71(4), 472-487. doi:10.1177/1080569908325862

Warkentin, M. E., Sayeed, L., \& Hightower, R. (1997). Virtual Teams versus Face-to-Face Teams: An Exploratory Study of a Web-based Conference System. Decision Sciences, 28(4), 975-996. doi:10.1111/j.1540-5915.1997. tb01338.x

Weimann, P., Pollock, M., Scott, E., \& Brown, I. (2013). Enhancing Team Performance Through Tool Use: How Critical Technology-Related Issues Influence the Performance of Virtual Project Teams. IEEE Transactions on Professional Communication, 56(4), 332-353. doi:10.1109/TPC.2013.2287571

Xu, J. (2007). Developing a Taxonomy of Characteristics and Features of Collaboration Tools for Teams in Distributed Environments. Retrieved from http://www.dtic.mil/cgi-bin/GetTRDoc?Location=U2\&doc=GetT RDoc.pdf\&AD=ADA47758 


\section{APPENDIX}

\section{Collaboration Software Survey}

The purpose of this survey is to obtain relevant information on the key features in Collaborative software. Collaboration Software, also known as groupware, are programs designed to integrate synchronous and asynchronous tools to facilitate team work. Members who work in a group project use collaborative software to communicate, see action plans, share documents, track projects, manage schedules, automate business processes, and be instantly notified about tasks and activities. In this survey, we would like to know what features are the most desired by people for groupware so we can evaluate different existing options available in the market and be able to frame a proposal to recommend a good solution that meets the majority of those desirable features. The survey may take you up to 10 minutes. Thank you for your time and help!

Q1 What's your gender?

O Male

O Female

Q2 What's your age group?

20 years or younger

○ 20-29

O 30-39

O 40-49

O 50+

Q3 What's your highest degree earned?

O High school

O Associate/tech degree (2 year)

O Some Undergraduate school

Undergraduate degree

Some graduate school

Graduate degree

Q4 What's your academic standing?

Oraduate student

Undergraduate - freshman

O Undergraduate - sophomore

Undergraduate - junior

O Undergraduate - senior

Q5 If you work or have worked, which of following best defines your position level?

O CIO/CTO/Executive

D Director/middle management

O Supervisory/Team Leader

O Professional (no subordinates)

Do not apply

Q6 How long have you been working?

Less than 3 years

3-5 years

6-9 years

$\mathrm{O}>=10$ years 
Q7 How many long term (at least 3 weeks long) team projects have you worked on?
O 0
O $1-2$
O $3-4$
5-6
O 6 or more

Q8 Have you ever used groupware/collaboration software in your team projects?
$\mathrm{O}$ Yes
O No

Q9 Please list the groupware/collaboration software you have used or you are familiar with (list the first the one you used most or know most, one entry per line). Write none if you never used a groupware

Q10 Please list the reason may prevent you from using a groupware/collaboration software in team work? (Check all that apply)

Not familiar with the groupware

The groupware is lack of features I want

The groupware is difficult to use

$\square$ Have to use more than one groupware for the team collaboration

The cost of the groupware

$\square$ Other. Please specify

Q11 If you work in a project team in an on-campus class, how useful do you think the groupware will help you with the team work?

O Least useful

Somewhat useful

O Neutral

O Useful

Very useful

Q12 If you work in a project team in an online course, how useful do you think the groupware will help you with the team work?
O Least useful
Somewhat useful
O Neutral
O Useful
Very useful

Q13 On a scale from 1 to 5 (1 - Very unimportant, 5 - Very important), please indicate your opinion on the importance of the features of a groupware

\begin{tabular}{|l|c|c|c|c|c|}
\hline & $\begin{array}{c}\text { Very } \\
\text { Unimportant }\end{array}$ & $\begin{array}{c}\text { Somewhat } \\
\text { Unimportant }\end{array}$ & Neutral & $\begin{array}{c}\text { Somewhat } \\
\text { Important }\end{array}$ & $\begin{array}{c}\text { Very } \\
\text { Important }\end{array}$ \\
\hline Document (file) and content Sharing & $\bigcirc$ & $\bigcirc$ & $\bigcirc$ & $\bigcirc$ & $\bigcirc$ \\
\hline Team Communication & $\bigcirc$ & $\bigcirc$ & $\bigcirc$ & $\bigcirc$ & $\bigcirc$ \\
\hline $\begin{array}{l}\text { Project Management (Task } \\
\text { management) }\end{array}$ & $\bigcirc$ & $\bigcirc$ & $\bigcirc$ & $\bigcirc$ & $\bigcirc$ \\
\hline $\begin{array}{l}\text { Additional features for Mobile } \\
\text { support, Interaction with Existing } \\
\text { Social Networking Sites, Language } \\
\text { Support, and others }\end{array}$ & $\bigcirc$ & $\bigcirc$ & $\bigcirc$ & $\bigcirc$ & $\bigcirc$ \\
\hline The groupware is free at no cost & $\bigcirc$ & $\bigcirc$ & $\bigcirc$ & $\bigcirc$ & $\bigcirc$ \\
\hline
\end{tabular}


Q14 Please indicate your opinion on the importance of the features listed below related to file and content sharing in a groupware program

\begin{tabular}{|c|c|c|c|c|c|c|}
\hline & $\begin{array}{c}\text { Very } \\
\text { Unimportant }\end{array}$ & $\begin{array}{c}\text { Somewhat } \\
\text { Unimportant }\end{array}$ & Neutral & $\begin{array}{l}\text { Somewhat } \\
\text { Important }\end{array}$ & $\begin{array}{c}\text { Very } \\
\text { Important }\end{array}$ & $\begin{array}{l}\text { I don't } \\
\text { know }\end{array}$ \\
\hline $\begin{array}{l}\text { Central Storage facility } \\
\text { (document repository) }\end{array}$ & O & O & O & O & O & O \\
\hline $\begin{array}{l}\text { Document check in and } \\
\text { check out }\end{array}$ & O & O & O & O & O & O \\
\hline Version control & O & O & ○ & O & O & O \\
\hline $\begin{array}{l}\text { Searching across } \\
\text { documents }\end{array}$ & O & O & O & O & O & O \\
\hline $\begin{array}{l}\text { Summary document } \\
\text { previews }\end{array}$ & $\bigcirc$ & O & O & O & O & O \\
\hline $\begin{array}{l}\text { Document conversion } \\
\text { (to other formats, } \\
\text { compatibility) }\end{array}$ & ○ & $\mathrm{O}$ & O & O & O & O \\
\hline $\begin{array}{l}\text { Document Subscription } \\
\text { for alerts on changes }\end{array}$ & ○ & O & O & O & O & O \\
\hline $\begin{array}{l}\text { Options to organize files } \\
\text { / documents in folders by } \\
\text { projects }\end{array}$ & ○ & O & $\bigcirc$ & O & $\bigcirc$ & O \\
\hline $\begin{array}{l}\text { Integrates with: } \\
\text { Dropbox, Box, Google } \\
\text { Drive, One Drive }\end{array}$ & O & $\bigcirc$ & O & O & $\bigcirc$ & $\mathrm{O}$ \\
\hline $\begin{array}{l}\text { Permissions to manage } \\
\text { access }\end{array}$ & ○ & O & O & O & O & O \\
\hline Other. Please specify & O & O & O & O & O & O \\
\hline
\end{tabular}


Q15 Please indicate your opinion on the importance of the features listed below related to Team Communication in a groupware program

\begin{tabular}{|c|c|c|c|c|c|c|}
\hline & $\begin{array}{c}\text { Very } \\
\text { Unimportant }\end{array}$ & $\begin{array}{l}\text { Somewhat } \\
\text { Unimportant }\end{array}$ & Neutral & $\begin{array}{l}\text { Somewhat } \\
\text { Important }\end{array}$ & $\begin{array}{c}\text { Very } \\
\text { Important }\end{array}$ & $\begin{array}{l}\text { I don't } \\
\text { know }\end{array}$ \\
\hline $\begin{array}{l}\text { Message boards for } \\
\text { topic discussion and } \\
\text { announcements }\end{array}$ & $O$ & O & O & O & O & O \\
\hline $\begin{array}{l}\text { Options for sharing group } \\
\text { calendars }\end{array}$ & $\bigcirc$ & $\bigcirc$ & O & $\bigcirc$ & O & 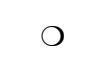 \\
\hline $\begin{array}{l}\text { Options to Schedule } \\
\text { Meetings dynamically and } \\
\text { flexibly }\end{array}$ & $O$ & $\bigcirc$ & $O$ & $O$ & $\bigcirc$ & $\bigcirc$ \\
\hline $\begin{array}{l}\text { Instant Messaging (chat) } \\
\text { with options to share } \\
\text { desktop, give control and } \\
\text { send files }\end{array}$ & $O$ & $\bigcirc$ & O & $\bigcirc$ & O & $\bigcirc$ \\
\hline $\begin{array}{l}\text { Audio (VoIP) / Video } \\
\text { conferencing options }\end{array}$ & $O$ & $\bigcirc$ & O & $\bigcirc$ & $\bigcirc$ & $O$ \\
\hline $\begin{array}{l}\text { Options for voice } \\
\text { communication }\end{array}$ & O & O & $O$ & $\bigcirc$ & $\bigcirc$ & $\bigcirc$ \\
\hline $\begin{array}{l}\text { Ability to call a } \\
\text { phone number such as } \\
\text { international and local } \\
\text { phone numbers }\end{array}$ & $\bigcirc$ & $\bigcirc$ & $O$ & $\bigcirc$ & O & 0 \\
\hline $\begin{array}{l}\text { Ability to perform } \\
\text { presentations online }\end{array}$ & 0 & 0 & 0 & O & O & O \\
\hline $\begin{array}{l}\text { Options for Document } \\
\text { Presentation during } \\
\text { meetings }\end{array}$ & O & O & O & O & O & O \\
\hline $\begin{array}{l}\text { Ability to view and edit } \\
\text { documents at the same time } \\
\text { as other group members }\end{array}$ & O & $\bigcirc$ & O & $O$ & $\bigcirc$ & $\bigcirc$ \\
\hline $\begin{array}{l}\text { Capabilities to record } \\
\text { meetings and share meeting } \\
\text { notes }\end{array}$ & O & O & $O$ & $\bigcirc$ & $\bigcirc$ & $O$ \\
\hline $\begin{array}{l}\text { Options to create polls and } \\
\text { surveys from discussion } \\
\text { topics (Polling) }\end{array}$ & O & O & O & $\bigcirc$ & $\bigcirc$ & $\bigcirc$ \\
\hline $\begin{array}{l}\text { Email and its common } \\
\text { characteristics and } \\
\text { compatibility with other } \\
\text { tools like outlook }\end{array}$ & O & O & O & O & O & 0 \\
\hline $\begin{array}{l}\text { Workflow feature to allow } \\
\text { documents to be routed } \\
\text { through process. }\end{array}$ & O & 0 & O & O & O & O \\
\hline Other. Please specify. & $\mathrm{O}$ & 0 & O & O & O & O \\
\hline
\end{tabular}


Q16 Please indicate your opinion on the importance of the features listed below related to Project Management in a groupware program

\begin{tabular}{|c|c|c|c|c|c|c|}
\hline & $\begin{array}{c}\text { Very } \\
\text { Unimportant }\end{array}$ & $\begin{array}{l}\text { Somewhat } \\
\text { Unimportant }\end{array}$ & Neutral & $\begin{array}{l}\text { Somewhat } \\
\text { Important }\end{array}$ & $\begin{array}{c}\text { Very } \\
\text { Important }\end{array}$ & $\begin{array}{l}\text { I don't } \\
\text { know }\end{array}$ \\
\hline $\begin{array}{l}\text { Options to create and } \\
\text { manage project Tasks }\end{array}$ & $\bigcirc$ & $\mathrm{O}$ & $\bigcirc$ & $\bigcirc$ & $\bigcirc$ & $\bigcirc$ \\
\hline $\begin{array}{l}\text { Capabilities to assign } \\
\text { tasks to team members } \\
\text { and track their progress }\end{array}$ & $\bigcirc$ & $\mathrm{O}$ & O & $\mathrm{O}$ & $\mathrm{O}$ & $\bigcirc$ \\
\hline Options to set milestones & $\bigcirc$ & $\bigcirc$ & O & $\bigcirc$ & O & $\bigcirc$ \\
\hline $\begin{array}{l}\text { Ability to Monitor team's } \\
\text { status and progress to } \\
\text { prevent bottlenecks }\end{array}$ & $\bigcirc$ & $\mathrm{O}$ & $\bigcirc$ & $\mathrm{O}$ & $\bigcirc$ & $\bigcirc$ \\
\hline $\begin{array}{l}\text { Options to balance team } \\
\text { workload }\end{array}$ & ○ & $\bigcirc$ & O & $\bigcirc$ & ○ & $\bigcirc$ \\
\hline Gantt charting & $\bigcirc$ & $\mathrm{O}$ & $\mathrm{O}$ & $\mathrm{O}$ & $O$ & $\mathrm{O}$ \\
\hline $\begin{array}{l}\text { Options for project } \\
\text { reports }\end{array}$ & ○ & $\bigcirc$ & O & $\mathrm{O}$ & O & O \\
\hline Other. Please specify & $\bigcirc$ & O & $\bigcirc$ & ○ & O & O \\
\hline
\end{tabular}


Q17 Please indicate your opinion on the importance of the additional features listed below related in a groupware program

\begin{tabular}{|c|c|c|c|c|c|c|}
\hline & $\begin{array}{c}\text { Very } \\
\text { Unimportant }\end{array}$ & $\begin{array}{l}\text { Somewhat } \\
\text { Unimportant }\end{array}$ & Neutral & $\begin{array}{l}\text { Somewhat } \\
\text { Important }\end{array}$ & $\begin{array}{c}\text { Very } \\
\text { Important }\end{array}$ & $\begin{array}{l}\text { I don't } \\
\text { know }\end{array}$ \\
\hline $\begin{array}{l}\text { Mobile accessibility to } \\
\text { join meetings, send instant } \\
\text { messages or give project } \\
\text { inputs through Apple or } \\
\text { Android devices }\end{array}$ & O & $\bigcirc$ & $\bigcirc$ & $\bigcirc$ & $\bigcirc$ & O \\
\hline $\begin{array}{l}\text { Options to interact with } \\
\text { existing Social Networking } \\
\text { Sites like Facebook or } \\
\text { MySpace }\end{array}$ & $\mathrm{O}$ & $\mathrm{O}$ & O & $\bigcirc$ & O & O \\
\hline $\begin{array}{l}\text { Capability for Wiki (Options } \\
\text { to view and edit websites } \\
\text { with project comments) }\end{array}$ & O & O & O & O & O & O \\
\hline $\begin{array}{l}\text { Blog options to facilitate } \\
\text { group discussions through } \\
\text { posts and comments. }\end{array}$ & O & $\mathrm{O}$ & O & O & O & O \\
\hline $\begin{array}{l}\text { Diversity Support (time } \\
\text { zones, meeting schedules, } \\
\text { support different languages) }\end{array}$ & O & $\mathrm{O}$ & $\mathrm{O}$ & O & $\mathrm{O}$ & O \\
\hline $\begin{array}{l}\text { Options for security like } \\
\text { anti-virus }\end{array}$ & O & O & O & O & O & O \\
\hline $\begin{array}{l}\text { Easiness of use (user } \\
\text { friendly Design) }\end{array}$ & $\mathrm{O}$ & O & O & O & $O$ & O \\
\hline Easy to install & O & O & O & $\mathrm{O}$ & $O$ & O \\
\hline $\begin{array}{l}\text { Online updates and } \\
\text { Technical Support }\end{array}$ & $\bigcirc$ & O & O & $\bigcirc$ & $O$ & O \\
\hline Other. Please specify & 0 & $\mathrm{O}$ & O & 0 & $\mathrm{O}$ & 0 \\
\hline
\end{tabular}


Yide Shen is an Assistant Professor of MIS in the Rohrer College of Business at Rowan University. She received her PhD in Computer Information Systems from Georgia State University. She also holds a MS in Management Information Systems from the University of Nebraska at Omaha. Her current research focuses on coordination effectiveness for distributed teams, individual decision-making in IT projects, and information systems pedagogy. Her research articles appear in refereed journals and conference proceedings, including Decision Support Systems, International Journal of e-Collaboration, Journal of Information Systems Education, and International Conference on Information Systems (ICIS).

Lei Li is an Associate Professor of Information Technology in the College of Computing and Software Engineering at Kennesaw State University. He received his PhD in Computer Information Systems from Georgia State University. His current research interests include data security, social media analytics, web information management, and IT education. His work has appeared in the Journal of Information Systems Education, Journal of Systems and Software, and various IS, ACM and IEEE conferences. He is a member of the Association of Information Systems, IEEE, and ACM Special Interests Group in IT Education (SIGITE).

Guangzhi Zheng is an Assistant Professor of Information Technology in the College of Computing and Software Engineering at Kennesaw State University. He received his PhD in Computer Information Systems from Georgia State University. His primary research and teaching interests include web and mobile applications, business intelligence, user interface, data visualization, and IT education. His research has appeared in the AIS Transactions on $\mathrm{HCl}$, Journal of Systems and Software, Journal of Information Technology, Journal of Information System Education, Information Systems Education Journal, and Journal of IT Education.

Rong Guo teaches in the Richard College of Business at the University of West Georgia. She earned her PhD in finance from Georgia State University. Her research interests and publication themes include corporate governance, mergers and acquisitions, internal capital markets, diversification and business education. Her current teaching and research also includes personal financial management and investments. 